\title{
ZRSR2 Gene
}

National Cancer Institute

\section{Source}

National Cancer Institute. ZRSR2 Gene. NCI Thesaurus. Code C101120.

This gene is involved in mRNA processing. 